\title{
Associations Between Global Population Health Indicators and Dialysis Variables in the Monitoring Dialysis Outcomes (MONDO) Consortium
}

\author{
Viviane Calice-Silva ${ }^{a, b}$ Rasha Hussein ${ }^{a}$ Dalia Yousifa Hanjie Zhang ${ }^{b}$ \\ Len Usvyat ${ }^{\text {b, c }}$ Ludimila G. Campos $^{a}$ Gero von Gersdorff ${ }^{d}$ Mathias Schaller ${ }^{d}$ \\ Danielle Marcellie Aileen Grassman ${ }^{e} \quad$ Michael Etter $^{f} \quad$ Xiaoqi Xu $^{f}$ \\ Peter Kotanko $^{b}$ Roberto Pecoits-Filho ${ }^{a}$ \\ ${ }^{a}$ School of Medicine, Pontificia Universidade Católica do Paraná, Curitiba, Brazil; ${ }^{b}$ Renal Research Institute, \\ New York, N.Y., ' Fresenius Medical Care North America, Waltham, Mass., USA; ${ }^{d}$ Cologne University Medical Center, \\ Cologne, ${ }^{e}$ Fresenius Medical Care Deutschland, Bad Homburg, Germany; ${ }^{\mathrm{f}}$ Fresenius Medical Care Asia Pacific, \\ Hong Kong, China
}

\section{Key Words}

Health indicators · Hemodialysis · End-stage renal disease · Renal replacement therapy

\footnotetext{
Abstract

Background: The number of patients receiving renal replacement therapy (RRT) increases annually and worldwide. Differences in the RRT incidence, prevalence, and modality vary between regions and countries for reasons yet to be clarified. Aims: Gain a better understanding of the association between hemodialysis (HD)-related variables and general population global health indicators. Methods: The present study included prevalent HD patients from 27 countries/ regions from the monitoring dialysis outcomes (MONDO) database from 2006-2011. Global population health indicators were obtained from the 2014 World Health Organization report and the Human Development Index from the Human
}

Development Report Office 2014. The Spearman rank test was used to assess the correlations between population social economic indicators and HD variables. Results: A total of 84,796 prevalent HD patients were included. Their mean age was 63 (country mean 52-71), and 60\% were males (country mean 52-85\%). Significant correlations were found between HD demographic clusters and population education, wealth, mortality, and health indicators. The cluster of nutrition and inflammation variables were also highly correlated with population mortality, wealth, and health indicators. Finally, cardiovascular, fluid management, and dialysis adequacy clusters were associated with education, wealth, and health care resource indicators. Conclusion: We identified socioeconomic indicators that were correlated with dialysis variables. This hypothesis-generating study may be helpful in the analysis of how global health indicators may interfere with access to $\mathrm{HD}$, treatment provision, dialytic treatment characteristics, and outcomes.

\section{KARGER 125}

(c) 2015 S. Karger AG, Base

0253-5068/15/0393-0125\$39.50/0

E-Mail karger@karger.com

www.karger.com/bpu
Roberto Pecoits-Filho, MD, PhD, FASN, FACP

School of Medicine, Pontificia Universidade Católica do Paraná

Rua Imaculada Conceição, 1155

Curitiba, PR 80.215-901 (Brazil)

E-Mail r.pecoits@pucpr.br 


\section{Introduction}

Renal replacement therapy (RRT), namely hemodialysis (HD), peritoneal dialysis (PD), and kidney transplantation has been used since the 1940s to treat endstage renal disease (ESRD) patients worldwide, and access to RRT is available in an increasing number of countries [1-4]. The number of patients on RRT has increased gradually, particularly in developing countries [5-8]. One of the most important reasons for this is because a broader population now has access to dialysis ensuring almost universal coverage including areas where previously patients had no access to treatment [7-9].

Differences in the RRT incidence, prevalence, and modality use vary broadly depending on region or country characteristics [10-12]. This can be partly explained by differences in social economic factors such as per capita gross domestic product (GDP), the proportion of GDP spend on health care, life expectancy at birth, and human development index (HDI) [9, 13-15]. The prevalence of RRT has increased particularly in countries with public health care systems and RRT insurance coverage, while the incidence increases independently of the degree of population coverage $[9,15,16]$.

Patient characteristics and dialysis practices also vary widely between countries [17]. Despite the growing number of comprehensive reports on ESRD populations and dialysis treatments at national and international levels such as United States Renal Data System (USRDS) reports, the European Renal Association European Dialysis and Transplant Association (ERAEDTA) reports, the Latin America Dialysis and Renal Transplant Registry (RLADTR), and Dialysis Outcomes and Practice Patterns Study (DOPPS) reports, there is still lack of information about the patterns of patient characteristics and dialysis variables in different areas of the world [18].

One of the most recent initiatives designed to improve our understanding of the epidemiology in patients with ESRD globally is the MONitoring Dialysis Outcome (MONDO) Initiative. MONDO, a consortium of multiple dialysis providers around the world, covering more than 40 countries, provides information about patients' demographic parameters, treatment characteristics, laboratory results, prescription data, as well as outcomes such as mortality and hospitalization $[19,20]$.

We hypothesize that global population health indicators may be associated with RRT access, treatment provision, dialytic treatment characteristics, and outcomes.
The aim of this study was to analyze the association between global population health indicators and ESRD patient profiles and characteristics in the MONDO cohort.

\section{Methods}

The study included prevalent ESRD patients undergoing maintenance HD from 27 countries/regions in the MONDO database from 2006 to 2011. Demographic and laboratory data were analyzed from dialysis unit records. Patients were considered prevalent when they survived at least one year on RRT. The average of years $1-3$ on dialysis was computed for continuous variables. Data concerning socioeconomic status indicators from each participating country were obtained from the 2014 World Health Organization's (WHO) global health report; data concerning Human Development Index (HDI) were obtained from the Human Development Report Office (HDRO) [21, 22] (table 1).

HDI is a summary measure of average achievement in key dimensions of human development: a long and healthy life, being knowledgeable and enjoying a decent standard of living. The HDI is the geometric mean of normalized indices for each of the three dimensions. The country classification according to HDI defines very high $\mathrm{HDI} \geq 0.8$; high $\mathrm{HDI}$ between 0.79 and 0.7 ; median HDI between 0.7 and 0.55 , and low $<0.55$. All countries with HD patient information documented in the MONDO database and global health indicators documented in the WHO and HDRO reports were included in the analysis.

In total, we analyzed 40 dialysis-related and 52 socioeconomic variables. These 92 variables were grouped into 6 dialysis-related and 6 population socioeconomic clusters. The six dialysis-related clusters were (a) demographics, (b) comorbidities, (c) nutrition and inflammation, (d) anemia, (e) mineral metabolism and electrolytes, and (f) cardiovascular/fluid management/dialysis adequacy. The six global population health clusters were (a) demographics, (b) education, (c) wealth, (d) population risk factors, (e) health care resources, and (f) mortality. The variables included in the respective clusters are shown in (tables 2, 3).

Descriptive analyses for continuous variables were reported as mean, minimum and maximum, and standard deviations. For categorical variables, the percentage of each category was reported. The Spearman rank test was used to access the correlations between social economic indicators and dialysis variables. A two-sided $\mathrm{p}<$ 0.05 was considered significant. In total, we computed 2,080 correlations. We then calculated the fraction of significant correlations $(\mathrm{p}<$ $0.05)$ per cluster. The fraction of significant correlations differed between clusters, ranging from 4.2 to $81.3 \%$, with a median of $20 \%$. Here we limit the presentation to HD clusters, which had at least 2 socioeconomic clusters with more than $20 \%$ of significant correlations. A correlation matrix plot was constructed to present the results. All the analyses were performed in R program - version 3.1.1.

\section{Results}

Data from 27 countries were used in these analyses. A total of 84,796 prevalent ESRD patients on HD were included. Their mean age was 63 years (country means $52-$ 


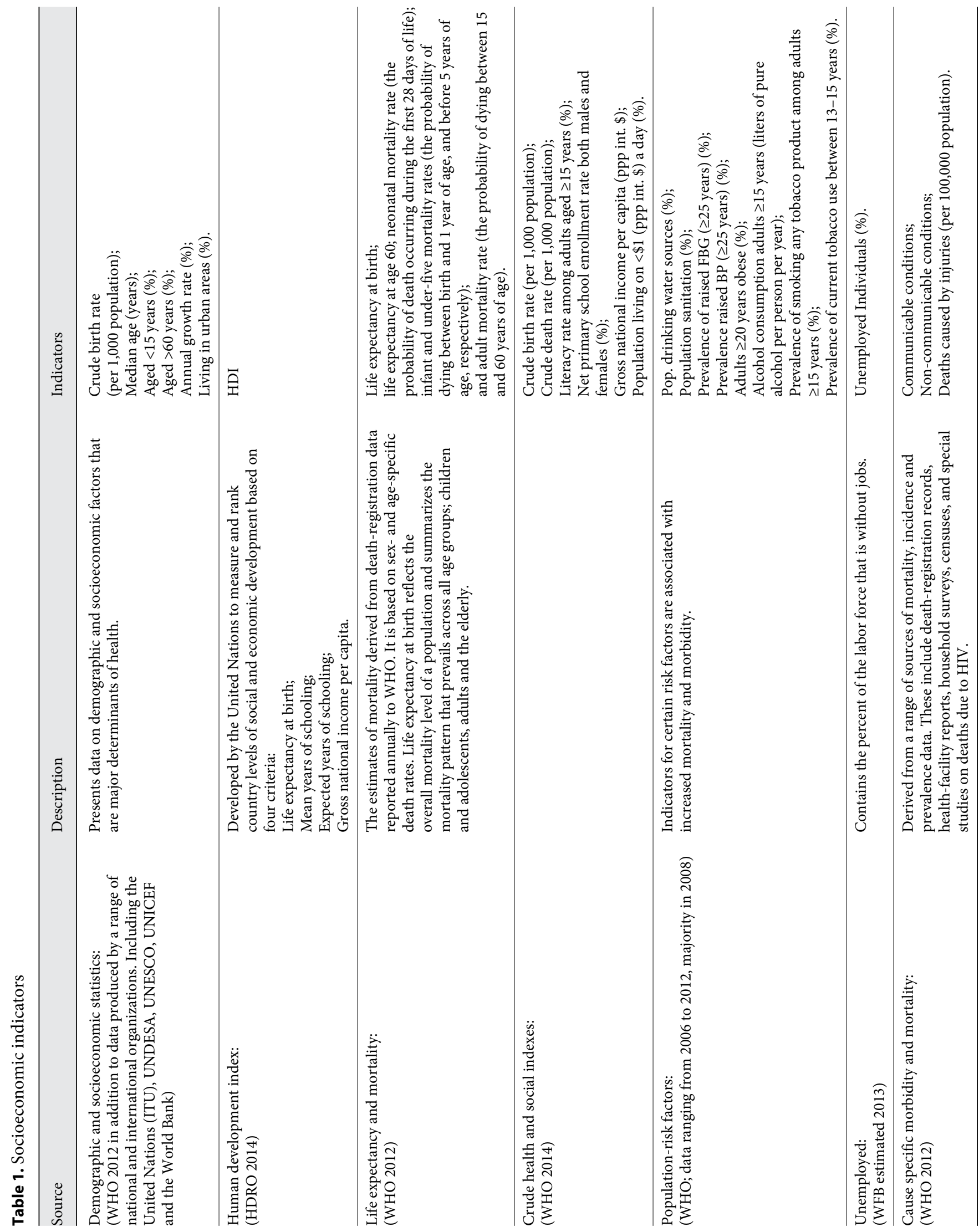




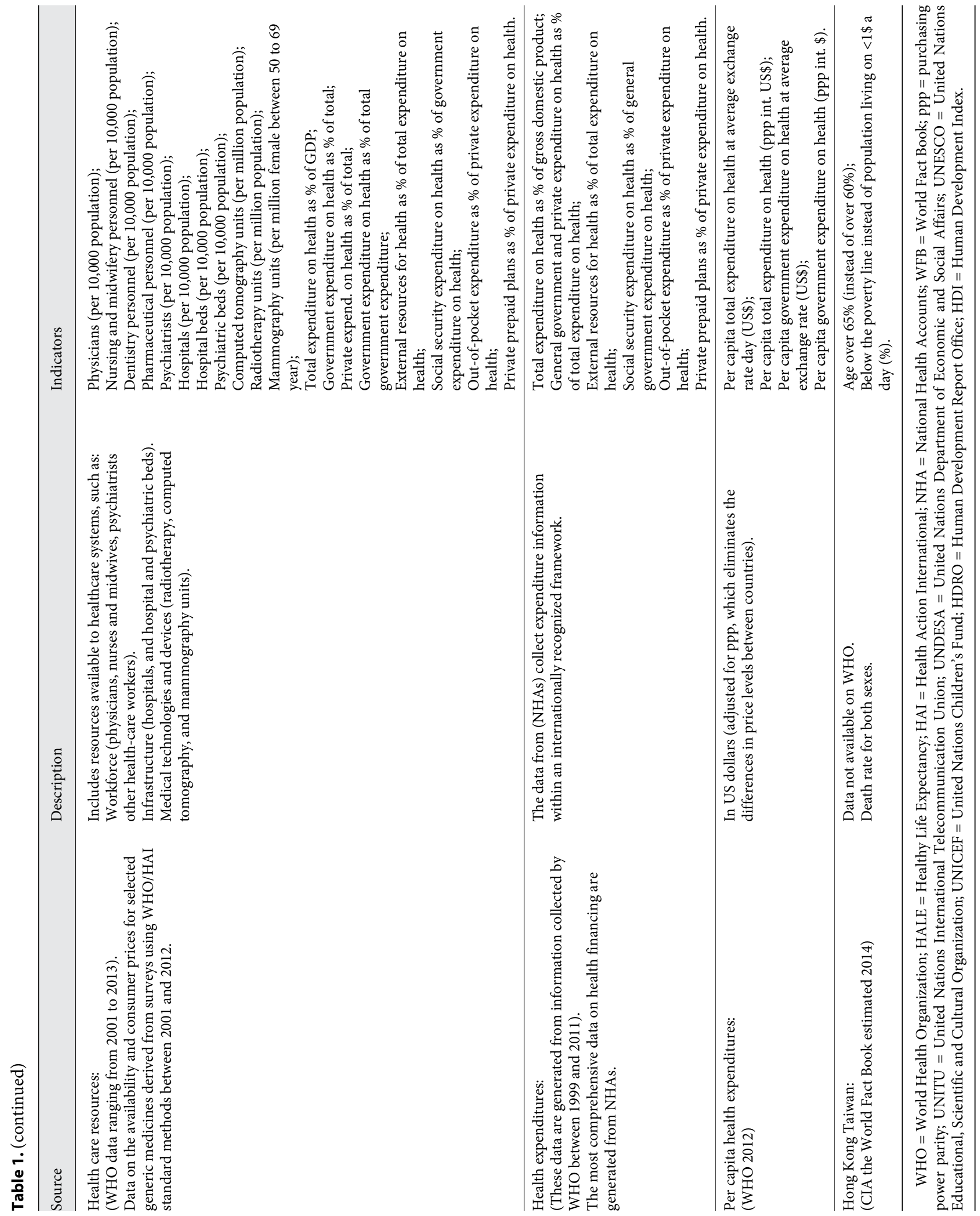


Table 2. Socioeconomic clusters

\begin{tabular}{|c|c|c|}
\hline Cluster & Abbreviation & Socioeconomic indicators \\
\hline Demographics & $\begin{array}{l}\text { B_Rte } \\
\text { M_Age } \\
\text { Age_blw_15 } \\
\text { Age_abv_60 } \\
\text { Gr_Rte } \\
\text { Urban }\end{array}$ & $\begin{array}{l}\text { Crude birth rate (per } 1,000 \text { population) } \\
\text { Median age (years) } \\
\text { Aged }<15 \text { years }(\%) \\
\text { Aged }>60 \text { years }(\%) \\
\text { Annual growth rate }(\%) \\
\text { Living in urban areas }(\%)\end{array}$ \\
\hline Population risk factors & $\begin{array}{l}\text { Water } \\
\text { Sanit } \\
\text { DM } \\
\text { Hyp } \\
\text { Obes } \\
\text { Alc } \\
\text { Smk_abv } 15 \\
\text { Smk_blw } 15\end{array}$ & $\begin{array}{l}\text { Population using improved drinking-water sources (\%) } \\
\text { Population using improved sanitation }(\%) \\
\text { Prevalence of raised fast blood glucose }(\geq 25 \text { years) (\%) } \\
\text { Prevalence raised blood pressure ( } \geq 25 \text { years) (\%) } \\
\text { Adults } \geq 20 \text { years obese (\%) } \\
\text { Alcohol consumption adults } \geq 15 \text { years (liters of } \\
\text { pure alcohol per person per year) } \\
\text { Prevalence of smoking adults } \geq 15 \text { years (\%) } \\
\text { Prevalence of tobacco use between } 13 \text { and } 15 \text { years }(\%)\end{array}$ \\
\hline Wealth & $\begin{array}{l}\text { HDI } \\
\text { GNI } \\
\text { Pop_blw_1\$ } \\
\text { Unempl }\end{array}$ & $\begin{array}{l}\text { Human Development Index (HDI) } \\
\text { Gross national income (ppp int. \$) } \\
\text { Population living on }<\$ 1 / \text { day (\%) } \\
\text { Unemployed }(\%)\end{array}$ \\
\hline Health care resources & $\begin{array}{l}\text { MDs } \\
\text { Nurses } \\
\text { Dentists } \\
\text { Pharm } \\
\text { Psych } \\
\text { Hosp } \\
\text { Hosp_Beds } \\
\text { Psych_Beds } \\
\text { CT } \\
\text { Rad_Th } \\
\text { Mammo } \\
\text { Hlth_Ex_T } \\
\text { Hlth_Ex_Gov } \\
\text { Hlth_Ex_Pri } \\
\text { Hlth_Exp\% } \\
\text { Hlth_Ext } \\
\text { Soc_Sec } \\
\text { OOP } \\
\text { Hlth_Ins } \\
\text { Hlth_T_Exp\$ } \\
\text { Hlth_PC_Exp } \\
\text { Hlth_PC_Exp Gov\$ } \\
\text { Hlth_PC_Gov } \\
\text { Pop }\end{array}$ & $\begin{array}{l}\text { Physicians (per } 10,000 \text { population) } \\
\text { Nursing and midwifery personnel (per } 10,000 \text { population) } \\
\text { Dentistry personnel (per } 10,000 \text { population) } \\
\text { Pharmaceutical personnel (per } 10,000 \text { population) } \\
\text { Psychiatrists (per } 10,000 \text { population) } \\
\text { Hospitals (per } 10,000 \text { population) } \\
\text { Hospital beds (per } 10,000 \text { population) } \\
\text { Psychiatric beds (per } 10,000 \text { population) } \\
\text { Computed tomography units (per million population) } \\
\text { Radiotherapy units (per million population) } \\
\text { Mammography units (per million female between } 50 \text { to } 69 \text { years) } \\
\text { Total expenditure on health as \% of GDP } \\
\text { Government expenditure on health as \% of total } \\
\text { Private expenditure on health as \% of total } \\
\text { Government expenditure on health as \% of total government expenditure } \\
\text { External resources for health as \% of total expenditure on health } \\
\text { Social security expenditure on health as \% of government expenditure on health } \\
\text { Out-of-pocket expenditure as \% of private expenditure on health } \\
\text { Private prepaid plans as \% of private expenditure on health } \\
\text { Per capita total expenditure on health at average exchange rate day (US\$) } \\
\text { Per capita total expenditure on health (ppp int. \$) } \\
\text { Per capita government expenditure on health at average exchange rate (US\$) } \\
\text { Per capita government expenditure on health (ppp int. \$) } \\
\text { Total population }\end{array}$ \\
\hline Mortality & $\begin{array}{l}\text { L_Exp_Brth } \\
\text { L_Exp_60 } \\
\text { Neo_Mort } \\
\text { Inf_Mort } \\
\text { Mort_blw_5yr } \\
\text { Mort_Adlt } \\
\text { CDR } \\
\text { Morb_Mort }\end{array}$ & $\begin{array}{l}\text { Life expectancy at birth (years) } \\
\text { Life expectancy at age } 60 \text { (years) } \\
\text { Neonatal mortality rate (per } 1,000 \text { live births) } \\
\text { Infant mortality rate (per } 1,000 \text { live births) } \\
\text { Under-five mortality rate (per } 1,000 \text { live births) } \\
\text { Adult mortality rate (per } 1,000 \text { population) } \\
\text { Crude death rate (per } 1,000 \text { population) } \\
\text { Cause-specific mortality and morbidity (all causes - per } 100,000 \text { population) }\end{array}$ \\
\hline
\end{tabular}


Table 3. Dialysis clusters

\begin{tabular}{|c|c|c|}
\hline Cluster & Abbreviation & Dialysis variables \\
\hline Demographics & $\begin{array}{l}\text { Age } \\
\text { Male }\end{array}$ & $\begin{array}{l}\text { Age } \\
\text { Male (\%) }\end{array}$ \\
\hline Comorbidities (\%) & $\begin{array}{l}\text { DM } \\
\text { CHF } \\
\text { HTN } \\
\text { Arr } \\
\text { All CVD } \\
\text { IHD } \\
\text { CVD not HTN } \\
\text { PAD/PVD } \\
\text { Malign }\end{array}$ & $\begin{array}{l}\text { Diabetes mellitus (\%) } \\
\text { Congestive heart failure } \\
\text { Hypertension (\%) } \\
\text { Arrhythmia (\%) } \\
\text { All cardiovascular diseases (\%) } \\
\text { Ischemic Heart Disease (\%) } \\
\text { CVD other than HTN (\%) } \\
\text { Peripheral arterial disease/Peripheral venous disease (\%) } \\
\text { Malignancy (\%) }\end{array}$ \\
\hline Anemia & $\begin{array}{l}\mathrm{Hb} \\
\text { Ferr } \\
\text { TSAT }\end{array}$ & $\begin{array}{l}\text { Hemoglobin }(\mathrm{g} / \mathrm{dl}) \\
\text { Ferritin }(\mathrm{ng} / \mathrm{ml}) \\
\text { Transferrin saturation index }(\%)\end{array}$ \\
\hline Mineral metabolism and electrolytes & $\begin{array}{l}\text { Phos } \\
\text { iPTH } \\
\mathrm{Ca} \\
\mathrm{HCO} 3 \\
\mathrm{Na} \\
\mathrm{K}\end{array}$ & $\begin{array}{l}\text { Phosphate }\left(\mathrm{PO}^{-} \mathrm{mg} / \mathrm{dl}\right) \\
\text { Intact parathormone }(\mathrm{pg} / \mathrm{ml}) \\
\text { Calcium }\left(\mathrm{Ca}^{+2}-\mathrm{mg} / \mathrm{dl}\right) \\
\text { Bicarbonate }\left(\mathrm{HCO}^{-}-\mathrm{mEq} / \mathrm{l}\right) \\
\text { Sodium }\left(\mathrm{Na}^{+}-\mathrm{mEq} / \mathrm{l}\right) \\
\text { Potassium }\left(\mathrm{K}^{+}-\mathrm{mEq} / \mathrm{l}\right)\end{array}$ \\
\hline
\end{tabular}

71), with the highest mean age in Hong Kong and the lowest in Russia. The mean percentage of males in this population was $61 \%$ (country means $52-85 \%$ ) with the highest percentage in Sweden (85\%) and the lowest in Taiwan (52\%). The proportion of diabetic patients was highest in the United States (54\%) and lowest in Sweden (5\%). The average percentage of others comorbidities and dialysis parameters per country is shown in tables 4-6.

Global population health indicators were extracted from the WHO 2014 report and from the HDRO report 
Table 4. Percentage of HD patient comorbidities per country/regions

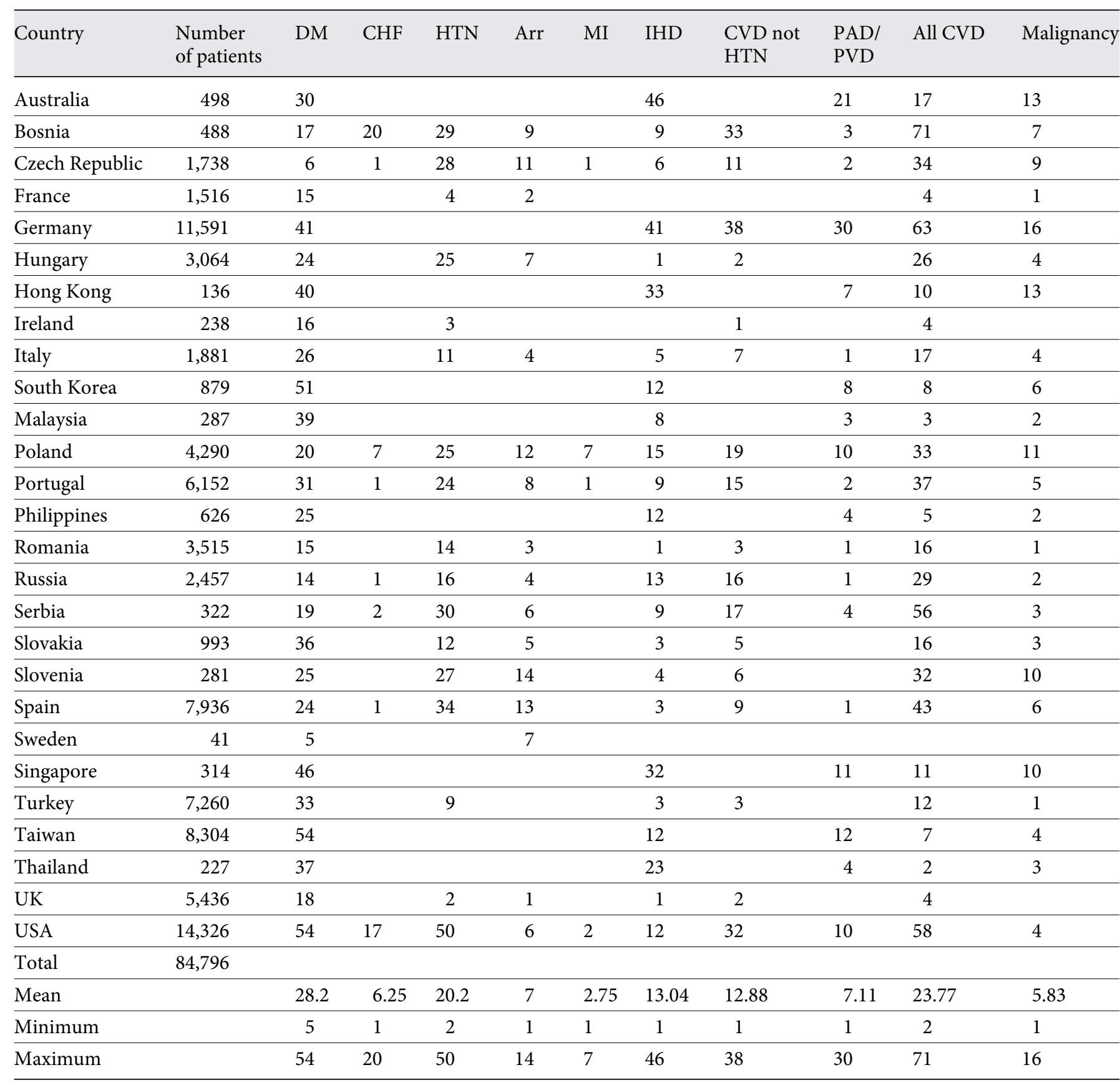

Abbreviations are shown in table 3.

(table 1). Most countries in this analysis have very high (17 countries) or high (9 countries) HDI, while it is low in the Philippines. Significant correlations between global health indicators and dialysis variables are presented in a correlation matrix plot (fig. 1).

Global Health Indicators in Dialysis Population
We found significant correlations between dialysis demographics cluster and mortality, wealth, and education clusters of population with a percentage of 81,63 , and $50 \%$ of correlations performed, respectively. The dialysis-related nutrition and inflammation cluster showed 
Table 5. HD patient comorbidities (in \%), countries combined

\begin{tabular}{lcrrr}
\hline Variable & $\begin{array}{l}\text { Number of } \\
\text { countries }\end{array}$ & Mean & Minimum & Maximum \\
\hline Diabetes & 27 & 28 & 5 & 54 \\
Congestive heart failure (CHF) & 8 & 6 & 1 & 20 \\
Hypertension (HTN) & 17 & 20 & 2 & 50 \\
All cardiovascular disease (CVD) & 26 & 24 & 2 & 71 \\
Arrhythmia (Arr) & 16 & 7 & 1 & 74 \\
Myocardial infarction (MI) & 4 & 3 & 1 & 46 \\
Ischemic heart disease & 24 & 13 & 1 & 38 \\
CVD not HTN & 17 & 13 & 1 & 30 \\
PAD/PVD & 19 & 7 & 1 & 16 \\
Malignancy (Malign) & 24 & 6 & 1 & \\
\hline
\end{tabular}

Table 6. HD variables; countries combined

\begin{tabular}{|c|c|c|c|c|c|}
\hline Variable & $\begin{array}{l}\text { Number of } \\
\text { countries }\end{array}$ & Mean & Minimum & Maximum & $\mathrm{SD}^{*}$ \\
\hline Age, years & 27 & 63.13 & 52.55 & 71.75 & 4.09 \\
\hline Male gender, \% & 27 & 61 & 52 & 85 & \\
\hline Albumin, g/dl & 27 & 3.81 & 3.53 & 4.10 & 0.14 \\
\hline Creatinine, mg/dl & 27 & 7.91 & 6.48 & 10.27 & 0.97 \\
\hline $\mathrm{BMI}, \mathrm{kg} / \mathrm{m}^{2}$ & 26 & 26.30 & 21.63 & 34.94 & 2.71 \\
\hline Cholesterol, mg/dl & 18 & 170.00 & 139.40 & 188.40 & 13.64 \\
\hline $\mathrm{LDL}-\mathrm{C}, \mathrm{mg} / \mathrm{dl}$ & 17 & 96.68 & 66.95 & 119.10 & 12.26 \\
\hline HDL-C, mg/dl & 17 & 45.40 & 35.18 & 53.89 & 4.29 \\
\hline $\mathrm{CRP}, \mathrm{mg} / \mathrm{l}$ & 25 & 12.42 & 1.39 & 34.58 & 6.98 \\
\hline $\mathrm{WBC}, 1,000 / \mathrm{mc}$ & 19 & 6.78 & 3.01 & 7.56 & 0.96 \\
\hline Hemoglobin, g/dl & 27 & 11.12 & 10.04 & 12.49 & 0.58 \\
\hline Ferritin, ng/ml & 27 & 503.50 & 291.20 & 764.90 & 128.50 \\
\hline TSAT, $\%$ & 26 & 29.81 & 21.51 & 36.26 & 3.42 \\
\hline Phosphate, mg/dl & 27 & 4.93 & 4.38 & 6.80 & 0.47 \\
\hline iPTH, pg/ml & 26 & 318.30 & 48.88 & $1,197.20$ & 210.70 \\
\hline Calcium, mg/dl & 27 & 8.95 & 8.62 & 9.32 & 0.19 \\
\hline Bicarbonate, $\mathrm{mEq} / \mathrm{l}$ & 25 & 22.48 & 20.56 & 24.33 & 1.12 \\
\hline Sodium, $\mathrm{mEq} / \mathrm{l}$ & 27 & 137.60 & 135.90 & 139.10 & 0.83 \\
\hline Potassium, mEq/l & 27 & 4.90 & 4.51 & 5.50 & 0.24 \\
\hline Pre-HD SBP, mm Hg & 27 & 141.40 & 128.00 & 151.60 & 6.39 \\
\hline Pre-HD DBP, mm Hg & 27 & 73.03 & 65.99 & 81.98 & 4.37 \\
\hline Post-HD SBP, mm Hg & 27 & 134.40 & 116.00 & 158.70 & 8.39 \\
\hline Post-HD DBP, mm Hg & 27 & 71.50 & 64.73 & 79.99 & 3.92 \\
\hline IDWG, \% of post-HD weight & 27 & 3.30 & 1.84 & 6.04 & 1.01 \\
\hline IDWG, $\mathrm{kg}$ & 27 & 2.28 & 1.43 & 4.05 & 0.59 \\
\hline Pre-HD weight, $\mathrm{kg}$ & 27 & 71.67 & 57.69 & 81.13 & 7.09 \\
\hline Post-HD weight, kg & 27 & 69.62 & 55.52 & 79.56 & 7.29 \\
\hline Treatment time, min & 27 & 240.50 & 213.10 & 270.20 & 13.88 \\
\hline Catheter, $\%$ & 27 & 31 & 8 & 59 & \\
\hline URR, \% & 27 & 73.75 & 69.74 & 77.89 & 1.97 \\
\hline $\mathrm{eKt} / \mathrm{V}$ & 27 & 1.43 & 1.21 & 1.82 & 0.11 \\
\hline
\end{tabular}

* Standard deviation. 


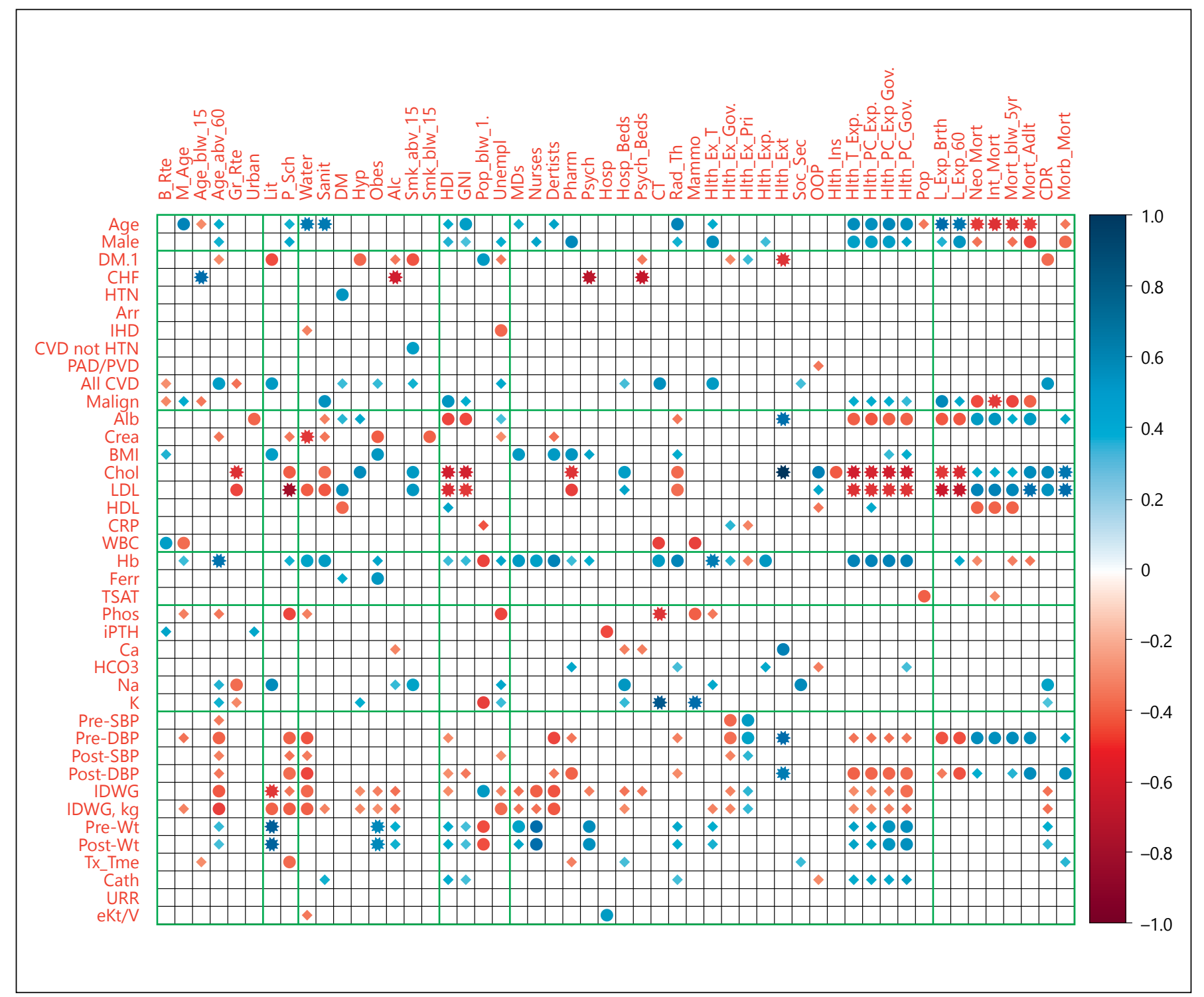

Fig. 1. The correlation matrix of HD variables and socioeconomic indicators. Blue color indicates positive correlation; red color indicates negative correlation, the color intensity and the shape of the symbols are both indicators of the strength of the correlation

a higher fraction of significant correlations with mortality $(40 \%)$, wealth $(31 \%)$, education $(25 \%)$, and population-risk factors (25\%). The dialysis-related anemia cluster was correlated with wealth $(33 \%)$, health care resources $(22 \%)$, mortality $(21 \%)$, and population-risk factors (21\%). The cardiovascular/fluid management/dialysis adequacy cluster correlated with education (41\%), wealth (31\%), and health care resources (25\%). Other clusters did not show more than $20 \%$ of significant correlations.

Global Health Indicators in Dialysis Population (square: correlation coefficient $<0.54$; circle: between $0.54-0.07$ and star: $\geq 0.7)$. Green lines delineate the clusters. Only correlations with $\mathrm{p}<0.05$ are shown. Abbreviations are shown in tables 2 and 3.

\section{Discussion}

Differences in the RRT incidence, prevalence, and modality vary depending on socioeconomic status of the region. In 2009, Yoshino et al. reported on a global level the correlations between mortalities in the general and HD populations in the respective countries [13]. In the present study, we extend that analysis by exploring associations between global population health indicators and dialysis variables in the international MONDO HD patient cohort.

Blood Purif 2015;39:125-136 
Patient demographics, anemia, nutrition, and cardiovascular assessment were HD clusters with large numbers of significant correlations associated with clusters of global health indicators.

Mortality, wealth, education, and health care resources indices were significantly correlated with the demographic dialysis cluster. The demographic variables associated with global health indicators included particularly age and percentage of males. These findings corroborate reports from the general population, since age, gender, and race are directly related to mortality, wealth, education, and health care resources [21,22]. The positive correlation coefficients between HD demographics and mortality (represented by life expectancy at birth and life expectancy at 60 years of age) could reflect an increase in access to RRT around the world, as well as an improvement in access to pre-dialysis care which delays HD initiation and extends survival [1-9]. The gross national income (GNI) from wealth cluster, the percentage of primary school enrolment in the general population, from education cluster, and the per capita total expenditure on health (US\$), and per capita government expenditure on health (PPP int. \$) from health care resources cluster were all positively correlated with the demographic cluster in dialysis population. RRT is an expensive therapy and can be responsible for $1-2 \%$ of health care expenditure in high income countries [23, 24]. Data from EVEREST study already showed the incidence of patients starting RRT is influenced by some certain macroeconomic factors including national wealth and economic structure $[14,15]$.

Particularly albumin and LDL cholesterol (LDL-C) as nutritional and inflammatory parameters (which are usually related to each other [24]) showed significant correlations with mortality, wealth, education, and populationrisk factors. Albumin is a surrogate marker of nutrition and inflammation strongly associated with HD mortality [25]. In a large international study of the MONDO cohort, Usvyat et al. showed a significant decrease of albumin levels in HD patients a few months before death [26]. LDL-C is more closely related to vascular calcification and the risk increase for arteriosclerosis and cardiovascular diseases, the leading cause of death in $\operatorname{HD}[27,28]$. Notable are the negative correlations between albumin and LDL-C with life expectancy at birth, life expectancy at 60 years, HDI and gross national income (GNI), and also between LDL-C and primary school enrolment.

The anemia cluster was highly correlated with wealth, health care resources, population risk factors, and mortality clusters. The hemoglobin $(\mathrm{Hb})$ level was the prin- ciple variable and was positively correlated with HDI and GNI and negatively correlated with poverty. $\mathrm{Hb}$ was also positively correlated with the number of physicians, nurses, pharmacists, dentists, and many variables related with health care expenditure, as well as with the population-risk factors percentage of population drinking water and sanitation. On the other hand, Hb levels were generally negatively correlated with mortality cluster variables neonatal death, death below age 5 , and adult mortality. Anemia is associated with mortality rate in the general population at different ages and can be related to diseases such as ESRD, malignancy, and heart disease [29, 30]. An effective treatment for anemia in ESRD patients depends on the availability of expensive medications, such as erythropoiesis stimulating agents (ESAs) and intravenous iron. Provision of these may be scarce in some countries when the consequence $\mathrm{Hb}$ target levels cannot be achieved and may affect patient outcomes $[31,32]$.

Finally, the variables of the cluster 'cardiovascular, fluid management and dialysis adequacy' were strongly correlated with the education, wealth and heath care resources clusters. Some studies have shown that the degree of literacy is associated with dialysis outcomes [33]. The cardiovascular, fluid management and dialysis adequacy cluster and the education cluster as represented by literacy and primary school enrolment were negatively correlated. Some examples from the cardiovascular, fluid management, and dialysis adequacy cluster are the significant correlations of the lower IDWG and better blood pressure control with the higher degree of literacy and primary school enrolment. A positive correlation between HD prevalence and wealth was previously described, showing that the lower the GPD (under US\$10,000), the higher the prevalence of ESRD $[6,7]$. Wealth can also interfere in the patient's treatment compliance [34]. Here HDI and GNI were negatively correlated with pre- and post-dialysis diastolic blood pressure, and positively correlated with pre- and post-dialysis weight and percentage of dialysis catheters. Modality choice, patient outcomes, and survival in dialysis population can be related to many health care resource indicators, such as pre-dialysis health care access, health care system sophistication (insurance or public health system coverage), number of healthcare personnel and facilities, social security support, and percentage of GDP spent on health care [35-44]. In this study, some negative correlations were found between blood pressures variables and health expenditure, and also between IDWG and percentage of physicians and nurses in the general population. 
This study has several limitations. First, the MONDO database does not comprise all HD patients of a given country. Consequently, the correlational analysis is incomplete. Second, the absence of some biologically plausible associations may reflect the heterogeneity of this group (27 countries). Third, testing for multiple correlations may result in spurious correlations. Fourth, some data are missing from the MONDO data base, especially comorbidity data. Fifth, socioeconomic indicators were not available from all countries. Sixth, we did not have the data to compare country-specific general population and MONDO data during the same years. Nevertheless, we believe that our study has merits. For the first time, we were able to study the associations between the characteristics of prevalent HD patients and health and macroeconomic factors in the respective background population of 27 countries. We were able to explore 40 dialysis variables and 52 global health indicators for the presence or ab- sence of associations in over $85,000 \mathrm{HD}$ patients. The study provides a panoramic view of the interrelationship between socioeconomic factors, access to RRT, and patient comorbidities, and outcomes.

This hypothesis-generating study may stimulate future analysis of how global health indicators may interfere in RRT access, treatment provision, dialytic treatment characteristics, and outcomes.

\section{Disclosure Statement}

RH and DY were fellows from the International Society of Nephrology (ISN) and received funding from the ISN for a Research Fellowship at Pontificia Universidade Católica do Paraná, Curitiba, Brazil during this manuscript elaboration. PK and LU hold stock in Fresenius Medical Care. RPF and VCS receive Scholarship from CNPq Brazilian Council for Research Support. The other authors have no financial interests to declare.

\section{References}

1 Annual Data Report. United States Renal Data System (USRDS) 2013: Chapter 11-13.

2 ERA-EDTA Registry: ERA-EDTA Registry Annual Report 2012. Academic Medical Center, Department of Medical Informatics, Amsterdam, the Netherlands, 2014.

-3 Cusumano AM, Garcia-Garcia G, GonzalezBedat MC, Marinovich S, Lugon J, PobleteBadal H, Elgueta S, Gomez R, HernandezFonseca F, Almaguer M, Rodriguez-Manzano S, Freire N, Luna-Guerra J, Rodriguez G, Bochicchio T, Cuero C, Cuevas D, Pereda C, Carlini R: Latin American Dialysis and Transplant Registry: 2008 prevalence and incidence of end-stage renal disease and correlation with socioeconomic indexes. Kidney Int Suppl 2013;3:153-156.

4 Pisoni RL, Greenwood RN: Selected lessons learned from the Dialysis Outcomes and Practice Patterns Study (DOPPS). Contrib Nephrol 2005;149:58-68.

5 Lysaght MJ: Maintenance dialysis population dynamics: current trends and long-term implications. J Am Soc Nephrol 2002;13:S37-S40.

-6 Moeller S, Gioberge S, Brown G: ESRD patients in 2001: global overview of patients, treatment modalities and development trends. Nephrol Dial Transplant 2002;17:2071-2076.

-7 Grassmann A, Gioberge S, Moeller S, Brown G: ESRD patients in 2004: global overview of patient numbers, treatment modalities and associated trends. Nephrol Dial Transplant 2005;20:2587-2593.

-8 Grassmann A, Gioberge S, Moeller S, Brown G: End-stage renal disease: global demographics in 2005 and observed trends. Artif Organs 2006;30:895-897.
-9 Rosa-Diez G, Gonzalez-Bedat M, Pecoits-Filho $\mathrm{R}$, et al: Renal replacement therapy in Latin American end-stage renal disease. Clin Kidney J 2014;7:431-436.

10 Jager KJ, Korevaar JC, Dekker FW, et al: The effect of contraindications and patient preference on dialysis modality selection in ESRD patients in The Netherlands. Am J Kidney Dis 2004;43:891-899.

11 Chugh KS, Jha V, Chugh S: Economics of dialysis and renal transplantation in the developing world. Transplant Proc 1999;31:32753277.

12 Caskey FJ, Kramer A, Elliott RF, Stel VS, Covic $A$, Cusumano $A$, Geue C, MacLeod AM, Zwinderman AH, Stengel B, Jager KJ: Global variation in renal replacement therapy for end-stage renal disease. Nephrol Dial Transplant 2011;26:2604-2610.

13 Yoshino M, Kuhlmann MK, Kotanko P, et al: International differences in dialysis mortality reflect background general population atherosclerotic cardiovascular mortality. J Am Soc Nephrol 2006;17:3510-3519.

14 Caskey FJ, Stel VS, Elliott RF, et al: The EVEREST study: an international collaboration. NDT Plus 2010;3:28-36.

15 Caskey FJ, Jager KJ: A population approach to renal replacement therapy epidemiology: lessons from the EVEREST study. Nephrol Dial Transplant 2014;29:1494-1499.

16 van de Luijtgaarden MW, Jager KJ, Stel VS, Kramer A, Cusumano A, Elliott RF, Geue C, MacLeod AM, Stengel B, Covic A, Caskey FJ: Global differences in dialysis modality mix: the role of patient characteristics, macroeconomics and renal service in- dicators. Nephrol Dial Transplant 2013;28: 1264-1275.

17 Chugh KS, Jha V: Differences in the care of ESRD patients worldwide: required resources and future outlook. Kidney Int Suppl 1995; 50:S7-S15.

18 Nissenson AR, Prichard SS, Cheng IK, Gokal R, Kubota M, Maiorca R, Riella MC, Rottembourg J, Stewart JH: ESRD modality selection into the 21st century: the importance of non medical factors. ASAIO J 1997;43:143-150.

19 Usvyat LA, Haviv YS, Etter M, Kooman J, Marcelli D, Marelli C, Power A, Toffelmire T, Wang Y, Kotanko P: The MONitoring Dialysis Outcomes (MONDO) initiative. Blood Purif 2013;35:37-48.

20 von Gersdorff GD, Usvyat L, Marcelli D, Grassmann A, Marelli C, Etter M, Kooman JP, Power A, Toffelmire T, Haviv YS, Guinsburg A, Barth C, Schaller M, Bayh I, Scatizzi L, Tashman A, Thijssen S, Levin NW, van der Sande FM, Pusey C, Wang Y, Kotanko P: Monitoring dialysis outcomes across the world - the MONDO Global Database Consortium. Blood Purif 2013;36:165-172.

21 World Health Statistics - Part III: Global Health Indicators. World Health Organization, 2014, pp 56-175.

22 Khalid Malik, et al: Human Development Report 2014 - Sustaining Human Progress: Reducing Vulnerabilities and Building Resilience. United Nations Development Program, 2014.

23 Martinsson A, Andersson C, Andell P, Koul $S$, Engström G, Smith JG: Anemia in the general population: prevalence, clinical correlates and prognostic impact. Eur J Epidemiol 2014; 29:489-498.
Global Health Indicators in Dialysis Population
Blood Purif 2015;39:125-136 DOI: $10.1159 / 000368980$ 
24 De Vecchi AF, Dratwa M, Wiedemann ME: Healthcare systems and end-stage renal disease (ESRD) therapies - an international review: costs and reimbursement/funding of ESRD therapies. Nephrol Dial Transplant 1999;14:31-41.

25 Nutrition in Chronic Renal Failure - KDOQI guideline. Am J Kidney Dis 2000;35(suppl 2):S9-S1022.

26 Usvyat LA, Barth C, Bayh I, Etter M, von Gersdorff GD, Grassmann A, Guinsburg AM, Lam M, Marcelli D, Marelli C, Scatizzi L, Schaller M, Tashman A, Toffelmire T, Thijssen S, Kooman JP, van der Sande FM, Levin NW, Wang Y, Kotanko P: Interdialytic weight gain, systolic blood pressure, serum albumin, and C-reactive protein levels change in chronic dialysis patients prior to death. Kidney Int 2013;84:149-157.

27 Wanner C, Tonelli M; Kidney Disease; Improving Global Outcomes Lipid Guideline Development Work Group Members: KDIGO Clinical Practice Guideline for Lipid Management in CKD: summary of recommendation statements and clinical approach to the patient. Kidney Int 2014;85:13031309.

28 K/DOQI Workgroup: K/DOQI Clinical Practices Guidelines for Cardiovascular Disease in Dialysis Patients. Am J Kidney Dis 2005; 45(suppl 3):S1-S153.

-29 Martinsson A, Andersson C, Andell P, Koul $S$, Engström G, Smith JG: Anemia in the general population: prevalence, clinical correlates and prognostic impact. Eur J Epidemiol 2014; 29:489-498.
30 Handelman GJ, Kotanko P, Cisternas MG, et al: Hospitalization and mortality in hemodialysis patients: association with hemoglobin variability. Blood Purif 2013;35:247-257.

31 KDOQI: KDOQI Clinical Practice Guideline and Clinical Practice Recommendations for anemia in chronic kidney disease: 2007 update of hemoglobin target. Am J Kidney Dis 2007;50:471-530.

32 Locatelli F, Nissenson AR, Barrett BJ, Walker RG, Wheeler DC, Eckardt KU, Lameire $\mathrm{NH}$, Eknoyan G: Clinical practice guidelines for anemia in chronic kidney disease: problems and solutions. A position statement from Kidney Disease: Improving Global Outcomes (KDIGO). Kidney Int 2008;74:1237-1240.

33 de Moraes PT, Figueiredo AE, Campos LG, Olandoski M, Barretti P, Pecoits-Filho R; BRAZPD Investigators: Characterization of the BRAZPD II cohort and description of trends in peritoneal dialysis outcome across time periods. Perit Dial Int 2014, in press

34 Loghman-Adham M: Medication noncompliance in patients with chronic disease: issues in dialysis and renal transplantation. Am J Manag Care 2003;9:155-171.

35 Yoder LA, Xin W, Norris KC, Yan G: Patient care staffing levels and facility characteristics in U.S. hemodialysis facilities. Am J Kidney Dis 2013;62:1130-1140.

36 Eisenstein EL, Sun JL, Anstrom KJ, et al: Do income level and race influence survival in patients receiving hemodialysis? Am J Med 2009;122:170-180.
37 Li PK, Chow KM: The cost barrier to peritoneal dialysis in the developing world - an Asian perspective. Perit Dial Int 2001;21(suppl 3):S307-S313.

38 Jung B, Blake PG, Mehta RL, et al: Attitudes of Canadian nephrologists toward dialysis modality selection. Perit Dial Int 1999;19: 263-268.

-39 Just PM, de Charro FT, Tschosik EA, et al: Reimbursement and economic factors influencing dialysis modality choice around the world. Nephrol Dial Transplant 2008;23: 2365-2373.

40 Docteur E, Oxley H: Health-care systems: lessons from the reform experience. OECD Health Working Paper No. 9 (Paris, Organization for Economic Co-operation and Development) 2003.

41 Couchoud C, Guihenneuc C, Bayer F, Lemaitre V, Brunet P, Stengel B; REIN Registry: Medical practice patterns and socio-economic factors may explain geographical variation of end-stage renal disease incidence. Nephrol Dial Transplant 2012;27:2312-2322.

42 Blake PG: The complex economics of modality selection. Perit Dial Int 2004;24:509-511.

43 Dor A, Pauly MV, Eichleay MA, et al: Endstage renal disease and economic incentives: the International Study of Health Care Organization and Financing (ISHCOF). Int $\mathrm{J}$ Health Care Finance Econ 2007;7:73-111.

44 Horl WH, de Alvaro F, Williams PF: Healthcare systems and end-stage renal disease (ESRD) therapies - an international review: access to ESRD treatments. Nephrol Dial Transplant 1999;14:10-15. 